\title{
Online first
}

International Organisations Research Journal, 2021, vol. 16, no 3, pp.

Trends in regional and global cooperation for sustainable development

Original article

doi:10.17323/1996-7845-2021-04-01

BACK TO THE IRON CAGE?

INSTITUTIONAL ISOMORPHISM OF THE AIIB ${ }^{1}$

J. Zhu, X. Hu

Jiejin Zhu - Professor, School of International Relations and Public Affairs, Fudan University, 220 Handan Road, Shanghai, 200433, China; Email: zhujiejin@fudan.edu.cn

Xinyu Hu - Master Student, School of International Relations and Public Affairs, Fudan University, 220 Handan Road, Shanghai, 200433, China; Email: xinyuhu17@fudan.edu.cn

\begin{abstract}
During its first five years of operation, the Asian Infrastructure Investment Bank (AIIB) is becoming more and more similar to traditional Multilateral Development Banks (MDBs) in terms of operational goals, business area, and environmental and social standards. Why has the AIIB, the newest type of multilateral development bank (MDB) initiated by an emerging economy, undergone institutional isomorphism? Based on the socialization theory, this paper argues that the institutional environment in which the AIIB is operating has a strong influence on AIIB's institution-building, mainly through the coercive, mimetic, and normative institutional isomorphic processes. On coercion, the pressures from European donors, international credit rating agencies, and global civil society have resulted in the AIIB's institutional isomorphism. On mimicking, the social uncertainty of the relationship between the AIIB and the Belt and Road Initiative
\end{abstract}

\footnotetext{
1 The article was submitted 5 August 2021
} 
and the technical uncertainty of infrastructure projects have triggered the AIIB's institutional isomorphism. On normativeness, the similar educational backgrounds and working experience of the AIIB's staff and active interactions among the MDB family members have caused the AIIB's institutional isomorphism. The paper concludes that the international institutional environment might hamper emerging economies' capabilities of institutional innovation.

Keywords: AIIB; New MDB; Traditional MDB; Institutional Isomorphism; Institutional Environment

For citation: Zhu J., Hu X. Back to the Iron Cage? Institutional Isomorphism of the AIIB. International Organisations Research Journal, vol.16, no 4, pp. (in English). DOI: https: //doi.org./10.17323/1996-7845-2021-04-01.

\section{Introduction}

The Asian Infrastructure Development Bank (AIIB) represents China's ambition to establish a new multilateral development bank (MDB) and innovate the global development finance system. Chinese president Xi Jinping addressed at the AIIB inauguration ceremony, "The founding of the AIIB means a great deal to the reforming global economic governance. It is consistent with the evolving trend of the global economic landscape and will help make the global economic governance system more just, equitable, and effective [Hu, Wang and Wang, 2016].'Former Chinese Finance Minister Xiao Jie also stressed at the Second Annual Meeting of AIIB's Board of Governors that the AIIB should exhibit its uniqueness and innovativeness as a 21 stcentury development bank and inject new vitality into the existing multilateral development system [Global Times, 2017].

Meanwhile, during its first five years of operation, the AIIB and traditional MDBs have become more alikeSocial infrastructure has become the latest investment trend of the AIIB in 2021 [AIIB, 2021a], challenging AIIB's original operational focus on productive sectors [AIIB, 2015a]. By 2019, AIIB had agreed to consider investing in coal-fired power plants if "they replace less efficient capacity or are essential to the reliability and integrity of the system, or if no viable or affordable alternative exists in 
specific cases" [AIIB, 2019a, Para.37]. However, at the annual meeting of the Climate Bonds Initiative in 2020, AIIB's President Jin Liqun pledged that AIIB would not finance any coal-fired power plants or any projects that are functionally related to coal [Farand, 2020]. In terms of environmental and social framework, China initially aimed to simplify the existing MDB's environmental and social safeguards. However, from 2016 to 2021, the AIIB has elevated the importance of climate change, gender equality, labor rights, and disability rights in its latest version of the environmental and social framework [AIIB, 2021b], deviating from the "result-oriented" and "risk-oriented" principles. It seems that the AIIB has moved away from its original plan and resembles other traditional MDBs such as the World Bank and the Asian Development Bank (ADB).

Why the AIIB, the newest multilateral development bank (MDB) initiated by an emerging economy, has undergone institutional isomorphism? Most existing research focuses on AIIB' s establishment, governance structure, as well as the great power competition within the AIIB [Chin, 2019; Freeman, 2019; Humphrey, 2019; Wang, 2016; Zhao, 2015; Chen, 2015; Luo and Yang, 2018; Zhu, 2018; Xu and Feng, 2019; Gu, 2019; Wang,2019; Ye, 2020]. Few researchers have paid attention to the institutional isomorphism of AIIB's institutions during its first five-year operation.

Based on the socialization theory, this paper argues that the institutional environment in which the AIIB is operating has a strong influence on AIIB's institutionbuilding. There are three main isomorphic processes, the coercive one, the mimetic one and the normative one. As for coercion, the pressures from European member states, international credit rating agencies, and global civil society have led to the AIIB's institutional isomorphism. As for mimicking, the AIIB's institutional isomorphism has been caused by the uncertain relationship between AIIB and Belt and Road Initiative and the technical complexity of infrastructure projects. As for normativeness, AIIB's staff shared similar educational and vocational background with other members of traditional MDBs. Active interactions also occur among the MDB family, thus causing the AIIB's institutional isomorphism. We conclude that the international institutional 
environment might hamper emerging economies' institutional innovation in global governance.

We suggest that this paper is critical both attheoretical and practical levels. We explore the mechanisms of international organizations' socialization process using the socialization theory of sociological institutionalism [Hall and Taylor, 1996]. Meanwhile, our focus on the AIIB, the first international financial institution initiated by China, has thought-provoking implications on the rising power and global governance reform. Have China enabled innovations in the China-initiated international organizations? What are the implications of AIIB's institutional isomorphism? How to deal with AIIB's isomorphic trend?

This paper has seven parts. In the part one, we have presented our research question. Second, we illustrate some evidence of the AIIB's institutional isomorphism during the last five years. Third, we introduce a theoretical framework of international organization socialization, including three isomorphic mechanisms - coercive, mimetic, and normative isomorphism. In the fourth, fifth, and sixth parts, we use coercive, mimetic, and normative mechanisms to explain the institutional isomorphism of the AIIB. In the last part, we discuss the implications of the AIIB's institutional isomorphism for the relationship between China rising and global governance reform.

\section{The operational institutional isomorphism of AIIB}

In a broad sense, institutions are artificial rules that govern human behaviors. During the start-up period, the AIIB has set up its institutional system. On the one hand, there are basic text institutions such as the Articles of Agreement of the Asian Infrastructure Investment Bank and Report on the Articles of Agreement of the Asian Infrastructure Investment Bank. The AIIB's governance structure, the voting power of each member, and general laws and rules for operations are defined in basic documents. Any amendments require a super majority voting among the board of governors, thus hard to be revised. On the other hand, there are operational institutions formulated by the staff of the AIIB and approved by the board of directors. AIIB's operational institutions consist of a series of operational policies and strategies established in the past five years, 
including Procurement Policy for Projects, Policy on Public Information, Energy Strategy, Environmental and Social Framework, Operational Policy on International Relations, and Water Strategy.

When evaluating AIIB's operational institutions, we find that the AIIB is becoming increasingly similar to the traditional MDBs mainly in three aspects, namely operational goals, business area, and environmental and social standards.

\section{Operational Goals}

According to the Articles of Agreement of the AIIB, one of the purposes of the Bank is to "foster sustainable economic development, create wealth and improve infrastructure connectivity in Asia" mainly through "promoting the investment of public and private capital in particular for the development of infrastructure and other productive sectors" [AIIB, 2015a, Art.1\&2]. AIIB President Jin Liqun also stressed in his speech at the Brookings Institute in 2015 that the productive sector would be the AIIB's priority lending area [Brookings Institute, 2015].

However, the dominant priority of the productive sector has been changed during the past five year. According to AIIB's first Corporate Strategy (2020-2030), climate finance has become one of the thematic priorities of the AIIB. By 2025, the Bank aims at reaching a 50 percent share of climate finance in the actual financing approvals [AIIB, 2020a]. In 2021, AIIB has incorporated social infrastructure into its newest investment trend and has planned to build a new specific department for social infrastructure [AIIB, 2021a]. This possible trend closely matches the distribution by sector trends at the World Bank and the ADB. The productive sectors' lending proportion at the World Bank declined from 54\% in 1976 to $28 \%$ in 2016. As for the ADB, the proportion declined from $36 \%$ in 1968 to $10 \%$ in 2016 [Kellerman, 2018].

Some members of the AIIB have some doubts on AIIB's corporate strategy. For example, at the AIIB's 2019 annual meeting in Luxembourg, the Egyptian Finance Minister pointed out that the AIIB member states have not agreed on the definition of the infrastructure that the AIIB prioritizes [Gabusi, 2019]. Chris Legg, AIIB's Australian member of the board of directors from 2016 to 2020, also raised out the 
question, "Should the AIIB extend its operations higher up the project cycle? How can it better address the needs of its low-income members without seeking additional grant resources?" [Legg, 2020].

\section{Business Area}

According to AIIB's energy strategy, coal accounted for 40 percent of Asia's energy consumption during 2000-2014, 11 percent higher than the global average [AIIB, 2019a]. Meanwhile, driven by their commitments to the 2015 Paris Climate Change Agreement, many developing countries focus more on nuclear energy. BRICS countries stated that they underlined the importance of predictability in accessing technology and finance to expand civil nuclear energy capacity. They believed that civil nuclear energy would contribute to the sustainable development of their countries [BRICS, 2016]. Based on developing countries' needs, AIIB President Jin Liqun at the Davos Forum in 2016 said that AIIB would consider coal-firing projects and nuclear projects if they meet AIIB's environmental and social standards. Jin also stated that the safety issues of the nuclear projects "can always be solved". [Tang and Liu, 2017].

Member states have disagreements on whether the AIIB should invest in coal and nuclear power projects. On the one hand, the AIIB's European members are all explicitly opposed to coal and nuclear power investment. On the other hand, during the consultation on energy strategy, coal-producing and oil-producing countries represented by Australia, Indonesia, and Saudi Arabia actively lobbied the AIIB to support the coal and nuclear power projects. Australia even addressed that coal and nuclear power play a central role in providing economic opportunity and better living standards for hundreds of millions of people in the east and south Asia [Hutchens, 2016]. Based on the fact that some members "have no viable alternative" other than coal-fired power [Gombar, 2017], the AIIB decided to consider investing in coal-related plants and civil nuclear energy if there are no other alternatives [AIIB, 2019a, Para.37].

However, at the annual meeting of the Climate Bonds Initiative in 2020, AIIB's President Jin Liqun pledged that AIIB would not finance any coal-related projects [Climate Home News, 2020]. When it comes to nuclear power, AIIB's latest energy 
strategy has made it clear that the AIIB would not finance any nuclear plants or develop highly specialized expertise in nuclear projects [AIIB, 2019a]. By ruling out the possibility of financing coal and nuclear projects, the AIIB becomes more and more similar to traditional MDBs, who have rejected financing coal and nuclear power after the 2015 Paris Climate Change Agreement.

\section{Environmental and Social Standards}

The AIIB's Environmental and Social Framework (ESF) was created in 2016 and amended through February 2019 and May 2021.

Initially, the Chinese proposal on the AIIB's ESF was a simplified version of MDB's environmental and social safeguards policies that is "risk-oriented" and "resultoriented". China pointed out that the ESFs of the traditional MDBs are usually a unified legal framework that incorporates many unrelated assessment criteria, which is unfriendly to borrowing countries and increases unnecessary operational costs [Zhu, 2018]. However, after two amendments, the AIIB's ESF closely resembles the safeguards policies of the traditional MDBs in several aspects.

Firstly, the AIIB has expanded its duty of regulating environmental and social risk. Based on the World Bank's Environmental and Social Standard 5 and 6, the AIIB adds Land Acquisition and Dam Safety rules into the 2019 version of ESF. The 2021 version explicitly incorporates regulatory rules on climate change, gender equality, labor rights, and disability rights [AIIB, 2021b]. The AIIB also widened the scope of the environmental and social assessment for its clients.

Secondly, the AIIB has tightened the responsibilities and obligations of its clients. The 2016 ESF only required private sector projects to establish a specific grievance mechanism for laborers. Nevertheless, the 2019 ESF clarifies that all clients should set up a labor grievance mechanism and effective information disclosure procedures. In addition, the AIIB also requires clients to estimate the greenhouse gas emissions of the whole project.

Third, the AIIB has added its responsibility for monitoring. The 2016 ESF approved its clients to adopt the "country system" under certain circumstances with a 
gap analysis comparing the country ESF to the AIIB's ESF [Gransow and Price, 2018]. However, in 2019, the ESF has made it clear that clients should adopt an environmental and social safeguards system that complies with the AIIB's policies and strategies. The Bank may also conduct an environmental and social action plan, if necessary, to ensure the compliance of the clients. Thus, it is less likely to apply the "country system" in future AIIB projects [AIIB, 2021b].

Overall, the AIIB is a clear example of institutional isomorphism during its first five years. Regarding operational goals, the AIIB might change its top priority on financing productive sectors. The AIIB has ruled out the possibilities of investing in coal and nuclear power projects regarding business areas. The AIIB has adopted a more comprehensive risk management framework regarding environmental and social policies, which is opposite to the initial Chinese proposal. To explaining this ongoing institutional isomorphism of the AIIB, we will draw on the socialization theory of sociological institutionalism to construct a theoretical framework for international organizations in the following section.

\section{Theoretical Framework: IO Socialization Theory}

Institutional isomorphism is a process that forces one organization to resemble other organizations in the same institutional environment and organization characteristics tend to become similar to environmental characteristics. The socialization theory of International Relations focuses on interactions among international actors in which actors will internalize certain norms of a given community within the international society and eventually become members of the international society. [Meyer and Rowan, 1977; DiMaggio and Powell, 1983; Checkel, 2005; Johnston, 2008; Guo, 2006;].

Two pioneers of sociological institutionalism, John Meyer and Brian Rowan, first explore the relation of organizations to their institutional environments. The institutional environment refers to the widely accepted social facts such as the legal system, cultural expectations, social norms, and the conceptual system. Thus, institutionalization is the process that the organization adopts these widely accepted 
characteristics of the institutional environment in which it operates. Organizations can gain more legitimacy and resources needed to survive, thus promoting their development throughout becoming isomorphic [Meyer and Rowan, 1977].

Based on Meyer and Rowan's research, Paul DiMaggio and Walter Powell operationalized the institutional environment and developed a middle-level theory of how the institutional environment shapes the institutional characteristics of organizations. Why do organizations adopt similar forms and practices? What are the causal mechanisms through which institutional isomorphic occurs? Under what condition do new organizations adopt the characteristics of the former organizations? DiMaggio and Powell propose three main causal mechanisms and corresponding empirical research hypotheses [DiMaggio and Powell, 1983].

The first is the coercive isomorphism. New organizations are forced to become isomorphic throughout the coercive mechanism by other actors that provide resources for the newcomer. Thus, coercive isomorphism is mainly related to the degree of dependence of the new organization. For example, although the companies themselves do not want to do so, they are forced by law to disclose their financial information to obtain various resources for going public. Therefore, we propose our first hypothesis:

Hypothesis 1: More dependent the new organization is on the resources in the institutional environment in which it operates, the more likely the new organization will experience institutional isomorphism.

The second is the mimetic isomorphism. When an organization has inadequate technologies, goals are ambiguous, or the environment has a high level of uncertainty, new organizations may model themselves on traditional organizations. For example, although most universities mainly focus on education and scientific research, the evaluation criteria are vaguer than that of companies, of which the main goal is to profit. Thus, the degree of imitation among universities is much higher than that among companies. Therefore, we propose our second hypothesis:

Hypothesis 2: The higher the level of uncertainty in the institutional environment in which a new organization operates, the more likely the new organization will experience institutional isomorphism. 
The third is the normative isomorphism. The third source of isomorphic organizational change is normative and stems primarily from professionalization. Professionalization and shared knowledge tend to lead to institutional isomorphism of the new organization since professionals "exhibit many similarities to their professional counterparts in other organizations" [DiMaggio and Powell, 1983]. For example, after China's reform and opening up, MNCs are much more similar than non-MNCs, since most of the staff recruited by MNCs have international education backgrounds and frequently participate in international activities and interactions. Thus, we propose our third hypothesis:

Hypothesis 3: The higher the degree of professionalization and idea-sharing in the institutional environment in which new organizations operate, the more likely the new organization will experience institutional isomorphism.

In a word, coercive, mimetic, and normative mechanisms are the principal causal mechanisms that lead to institutional isomorphism. It is worth mentioning that as a middle-level theory, the socialization theory integrates theoretical elements of rationalism and constructivism. Therefore, three institutional isomorphism mechanisms are not entirely isolated but interconnected in an empirical setting. While the coercive mechanism and the mimetic mechanism derive from the perspective of the survival and development of the organization, the normative mechanism derives from constructivism, emphasizing the power of shared ideas.

Next, we will draw on and apply this analytical framework (see Figure 1) to explain the institutional isomorphism of the AIIB.

Figure 1 The socialization mechanisms of the AIIB

\begin{tabular}{|c|c|c|c|}
\hline IV & Mechanisms & Condition & DV \\
\hline \multirow{4}{*}{$\begin{array}{l}\text { The } \\
\text { institutional } \\
\text { environment } \\
\text { the AIIB lies in }\end{array}$} & Coercive & Resource Dependence & \multirow{4}{*}{$\begin{array}{l}\text { The } \\
\text { institutional } \\
\text { isomorphism } \\
\text { of the AIIB }\end{array}$} \\
\hline & & Uncertainty & \\
\hline & Mimetic & & \\
\hline & Normative & & \\
\hline
\end{tabular}


Source: drawn by the author.

Coercive mechanism and the institutional isomorphism of the AIIB

As a new MDB, AIIB wants to be genuinely international, so it is dependent on the resources of its member states, the international credit rating agencies, and the international civil society, which are the fundamental reasons for the AIIB's institutional isomorphism.

Firstly, AIIB's member states. Members of the AIIB, especially the European nonborrowing countries, have exerted pressure on the AIIB to become a high-standard MDB like the World Bank and the European Banks [Wilson, 2019]. Many nonborrowing founding members decided to join the AIIB to ensure that the AIIB embodies the best standards in accountability, transparency, and governance [UK Government, 2015]. For example, UK stated that the AIIB's Environmental and Social Framework is the primary evidence of whether the AIIB meets the best standards for European powers [AIIB, 2020b]. France stated that European countries leveraged the negotiations to join the AIIB to promote the global climate change agenda [Gabusi, 2019]. Germany stressed that the AIIB should rule out support for projects involving nuclear energy [Germany Federal Ministry of Finance, 2019]. Meanwhile, according to the AIIB agreement, no less than three-fourths of the total voting power is required to establish policies for the AIIB [AIIB, 2015a, Art.26, Para. 2]. Since European constituencies account for $22.8 \%$ of the total voting power, and the non-borrowing members within the AIIB account for $36.155 \%$, European members and non-borrowing countries are critical for the AIIB's policy-making.

During the past five years, European members do have a significant impact on the AIIB institution-building. As for the accountability mechanism, European members mentioned in the AIIB's agreement that there should be an oversight mechanism for the operation of the AIIB that is in line with principles of transparency, openness, independence, and accountability [AIIB, 2015a, Art.26, Para.4]. In 2018, European powers represented by Germany and the UK urged the AIIB to clarify the division of responsibilities between the management and the Board of Directors under the 
Accountability Framework [Germany Federal Ministry of Finance, 2019]. The Accountability Framework of the AIIB allows the Board of Directors to supervise the AIIB's president and conduct annual evaluations [AIIB, 2018a]. Australia, Austria, Switzerland, Sweden, and Poland have explicitly appreciated the new Accountability Framework [AIIB, 2019b]. As for the energy strategy, the objections of many European countries against the coal and nuclear-related projects have pushed the AIIB to abandon the investment of coal and nuclear projects [Germany Federal Ministry of Finance, 2019; AIIB, 2020b].

The second is the international credit rating agencies. The ability of AIIB to raise resources from capital markets is critical for the AIIB to operate as a truly international MDB. By September 2020, the AIIB had issued bonds of US\$9 billion, accounting for one-third of its total assets, and most AIIB bonds are in US dollars and British pounds [AIIB, 2020c]. Generally speaking, the higher the credit rating of a multilateral development bank has, the lower the interest rate required to issue bonds [Humphrey and Michaelowa, 2013]. Therefore, the credit ratings given by international credit rating agencies are essential for the AIIB to reduce the cost of bonds issuance and to improve its ability to raise financial resources.

The three major international credit rating agencies, Moody's, Standard \& Poor's, and Fitch, all have required the AIIB to meet the standards of the traditional MDBs such as the World Bank and the ADB (see Table 1). For example, S\&P's 2017 report clearly expressed its expectations that AIIB would have the same high standards as the ADB and the World Bank Group institutions. Moody's 2017 rating report urged the AIIB's risk management processes and corporate governance to evolve consistent with the highest-rated MDBs. Otherwise, they may downgrade the rating of the AIIB. These agencies also expressed their appreciation of the AIIB's establishment of the risk management framework and the Project-affected People's Mechanism and the revision of the ESF [AIIB, 2021c]. President Jin Liqun also said, "It is not easy for the AIIB to get a $3 \mathrm{~A}$ credit rating. The $3 \mathrm{~A}$ rating is different from a Ph.D., which is for life. If the Bank does not operate well, the rating can be downgraded at any time. Therefore, we have to work tirelessly." 
Since sustainable development bonds have accounted for most of the AIIB's bonds and the environmental, social, and governance (ESG) issues rank highly on the AIIB's agenda, the ESG rating given by rating agencies is also essential for the AIIB. In the past, international rating agencies focused mainly on the financial performance of the MDBs rather than their performance on ESG [Ye, 2020]. However, ever since 2019, the three major international credit rating agencies have launched ESG credit rating systems. Investors have also paid more attention to ESG rating reports. ISS-oekom's 2019 ESG report stated that AIIB's performance on climate change and related risks is below the industry average [ISS-oekom, 2019]. In this context,

AIIB announces the exclusion of the coal-related investments and intends to significantly increase the share of climate finances to $50 \%$ of the total investment.

Table 1 The Requirements and Concerns of the three international rating agencies on the AIIB

\begin{tabular}{|c|c|c|c|}
\hline & Moody's & Standard \& Poor's & Fitch \\
\hline $\begin{array}{l}\text { Consistent with other } \\
\text { highest-rated MDBs }\end{array}$ & $\begin{array}{l}\text { Explicitly require the } \\
\text { AIIB to be consistent } \\
\text { with other highest- } \\
\text { rated MDBs }\end{array}$ & $\begin{array}{l}\text { Explicitly require the } \\
\text { AIIB to be consistent } \\
\text { with other highest- } \\
\text { rated MDBs }\end{array}$ & $\begin{array}{l}\text { Mentioned when } \\
\text { evaluating the risk } \\
\text { management } \\
\text { framework }\end{array}$ \\
\hline Focusing area & $\begin{array}{l}\text { Risk management; } \\
\text { Corporate } \\
\text { governance }\end{array}$ & $\begin{array}{l}\text { Environmental and } \\
\text { social risk } \\
\text { management; } \\
\text { Corporate } \\
\text { governance }\end{array}$ & Risk management \\
\hline Focusing policies & $\begin{array}{l}\text { the Project-affected } \\
\text { People's Mechanism; } \\
\text { Accountability } \\
\text { Framework; Risk } \\
\text { Management } \\
\text { Framework }\end{array}$ & $\begin{array}{l}\text { Environmental and } \\
\text { Social Framework; } \\
\text { Risk Management } \\
\text { Framework; } \\
\text { Accountability } \\
\text { Framework }\end{array}$ & $\begin{array}{l}\text { Risk Management } \\
\text { Framework }\end{array}$ \\
\hline
\end{tabular}

Reference: AIIB, 2021c, compiled by the author.

The third is the global civil society. Civil society organizations have been following both performances and policies of the AIIB since its establishment. NGOs such as Accountability Counsel, Inclusive Development have actively participated in the public consultation process of the AIIB's institutional development, suggesting that the AIIB 
as a new type of multilateral development bank should meet the "highest international standard". Accountability Counsel even expects that the AIIB could become the leading member of the MDB, while Inclusive Development becomes an advocate for the AIIB's Project-affected People's Mechanism and enhancing its visibility among residents. Meanwhile, Bank Watch and German Watch have become critical third-party supervisors by tracking the impact of some controversial AIIB projects on residents and the environment.

NGOs had played an important role in forcing the AIIB to abandon coal-related projects. NGOs, including Youth for Climate and Extinction Rebellion, had held several demonstrations outside of the pavilion of the AIIB's Luxembourg annual meeting, urging AIIB to rule out coal-related projects and pay more attention to the risk management of hydropower projects. [Geary, 2019] Meanwhile, the Big Shift Campaign has called on people to email the AIIB, pushing the AIIB to develop a more ambitious climate action plan and shift its investments away from fossil fuels [The Big Shift Campaign, 2019].

The AIIB also values advice and critics given by civil society organizations. AIIB's Vice President for Policy and Strategy, Joachim von Amsberg, once wrote back to NGO Forum on ADB that the AIIB would cover some of the points NGO raised in their recommendations, including carefully reviewing projects related to FI financing and interacting with other MDBs to learn lessons from their operations [Accountability Counsel, 2018]. Moreover, the AIIB has also made public the comments and suggestions received during the public consultation period, showing AIIB's appreciation of the participation of civil society organizations [AIIB, 2016].

Overall, from 2015 to 2020, pressures from those who provides resources for AIIB like European member states, international credit rating agencies, and global civil society have led to the institutional isomorphism of the AIIB, which is consistent with our first hypothesis:

Hypothesis 1: More dependent the new organization is on the resources in the institutional environment in which it operates, the more likely the new organization will experience institutional isomorphism. 
Mimetic mechanism and the institutional isomorphism of the AIIB

A rational strategy for a new organization to adapt to an institutional environment with a high level of uncertainty is to imitate the established organizations. During the first five years of the AIIB, the social uncertainty arising from the relationship between the AIIB and the "Belt and Road Initiative"(BRI), and the technical uncertainty stemming from the AIIB's relatively high-risk infrastructure investments are two crucial reasons for the AIIB to model itself on traditional MDBs.

On the one hand, the AIIB and the Belt and Road Initiative (BRI) have an ambiguous relationship, which negatively affects the AIIB's legitimacy as a real multilateral institution and raises social uncertainty. The AIIB and the BRI are all international cooperation initiatives proposed by China around 2013, focusing on infrastructure and interconnectivity. Thus, the AIIB has been regarded as a bank for the BRI. Raffaello Pantucci from the Royal United Services Institute regards the AIIB as a tool of the "Belt and Road" rather than a new independent financial institution, because $75 \%$ of the AIIB's projects are related to Belt and Road countries [Pantucci, 2016]. Once the AIIB's international and multilateral characteristics have been questioned, its credit ratings, ability to access high-quality projects, and co-financing with other MDBs will be badly influenced.

The AIIB President, Jin Liqun, has clarified the AIIB's relationship with the BRI. He stated that the AIIB and the BRI are "distinct and separate entities. As a highstandard international organization, AIIB has its standards in choosing the projects, including the debt sustainability, environmental protection and local people support" [The Paper, 2019]. Vice President Joachim von Amsberg further stressed that "if a project comes to you, and it is Belt and Road Initiative, are you going to invest it? Well, we could, but just because it is BRI does not mean we will” [VOA, 2017; Zhu, 2019].

However, as the saying goes, "Actions speak louder than words." The best way to deal with the social uncertainty is to adopt rules and policies consistent with the existing MDBs. Just as President Jin Liqun said at the Brookings Institute, "No one would question the AIIB when we adopt institutions of the World Bank and the ADB" 
[Brookings Institute, 2021]. Chris Humphrey, a leading scholar on MDBs, also stated that while there is still room for improvement in the existing MDBs, many officials have already felt satisfied if the AIIB can take the similar rules to these existing MDBs [Humphrey, 2019].

On the other hand, infrastructure projects bring technical uncertainty for the AIIB. Although focusing on infrastructure-related sectors is a comparative advantage of the AIIB within the MDB family, the AIIB has to manage the higher risks and raise more money for infrastructure projects. From 2016 to March 2021, the AIIB has 27 "Category A" projects that may have significant adverse environmental and social impacts that are irreversible, cumulative, diverse, or unprecedented, and has 47 "Category B" projects that may have limited impacts on environmental and social aspects [AIIB, 2021b]. The new-establishing AIIB has to manage those risks and face higher levels of technical uncertainties.

For instance, in 2016, the AIIB co-financed the Trans Anatolian Natural Gas Pipeline Project (TANAP project) with the World Bank, the European Bank for Reconstruction and Development (EBRD), the European Investment Bank (EIB), and the ADB. Controversial land acquisition for the pipeline project led to strong opposition by the local communities [Bankwatch Network, 2016]. In 2017, the AIIB's cofinancing project, the Hydropower plant project in Georgia, raises concerns about dam safety, the protection of the fragile river and mountain ecosystems, and the livelihoods of the local indigenous communities [Bankwatch Network, 2017]. In 2019, the AIIB and the World Bank jointly financed the Amaravati Sustainable Capital City Development Project. Involuntary resettlement evidence and negative influence on marginalized people led to the withdrawal of the World Bank and AIIB [BIC, 2019].

Thus, the AIIB has begun to imitate the institutional frameworks and standard practices of the existing MDBs in project approval, risk evaluation and management, and bank operations to address risks effectively and efficiently. For instance, the 2021 ESF incorporates dam safety and land acquisition regulations based mainly on the World Bank's ESS4 and ESS5 [World Bank, 2018a; World Bank, 2018b]. After modeling itself on the existing MDBs, however, the AIIB has gradually moved away 
from its initial "results-oriented" and "risk-oriented" principles and has begun to align itself with the comprehensive risk management systems of the World Bank or the ADB.

Overall, the AIIB faces high uncertainties revive from the ambiguous relationship between the AIIB and the BRI and the technical uncertainties derived from the vast infrastructure projects. Thus it is reasonable for the AIIB to imitate the existing MDBs, which is consistent with our second hypothesis:

Hypothesis 2: The higher the level of uncertainty in the institutional environment in which a new organization operates, the more likely the new organization will experience institutional isomorphism.

Normative mechanism and the institutional isomorphism of the AIIB

New organizations are more likely to experience institutional isomorphism if their staff have similar educational and vocational backgrounds with their counterparts of traditional organizations and if organizations are in a highly professionalized institutional environment with shared ideas and norms. Most senior management and staff of the AIIB have educational experiences in prestigious universities in the UK or the USA. Many also have rich experiences working in other international financial institutions. Thus, the normative mechanism is also an essential causal mechanism that led to the AIIB's institutional isomorphism.

AIIB's senior management responsible for institution-building generally has Western educational backgrounds and formal working experience in traditional MDBs. Natalie Lichtenstein, the first General Counsel of the AIIB who had made significant contributions to the Articles of the agreement of the AIIB, was graduated from Harvard University and had worked at the World Bank for nearly 30 years. Gerald Sanders, the General Counsel of the AIIB from 2016 to 2020, holds law degrees from Victoria University of Wellington and Harvard University. He also spent nearly 20 years at the EBRD. Joachim von Amsberg, the Vice President for Policy and Strategy, had been the World Bank's Vice President for 25 years and had actively participated in the revision of the World Bank's ESF. Hamid Sharif, responsible for the AIIB's Complaintsresolution, Evaluation, and Integrity Unit, had worked for the ADB's oversight 
mechanism for eight years. Standard \& Poor's report also stated that the AIIB's diverse and experienced senior management team is a fundamental reason why the S\&P decides to give the AIIB 3A ratings [AIIB, 2021c].

In addition to the senior management, the AIIB also emphasized working experiences in traditional MDBs in recruiting its staff. President Jin Liqun said that the newly-established AIIB is in great need of experienced staff who have experience in other international financial institutions as "seed players" to help train young staff and get the AIIB's operations on track [Caixin News, 2016]. For example, when recruiting for the Project-affected People's Mechanism, the AIIB required candidates to have at least 8-10 years of international professional experience working in infrastructure sectors and have experience in applying environmental and social safeguard policies [Devex, 2019].

Moreover, the AIIB is also an active member within the so-called "MDB family", seeking opportunities to co-finance with other MDBs and participating in policy dialogues among MDBs. As for co-financing, the AIIB had signed co-financing frameworks with MDBs, including the World Bank Group, ADB, EIB, EBRD [World Bank,2016; ADB,2016; EBRD,2016]. Until 2020, the AIIB has co-financed 30 projects with the World Bank, 19 projects with the ADB, and 5 projects with the EBRD [AIIB, 2021d].

As for policy dialogues, on the one hand, the AIIB conducts benchmarking exercises with other MDBs during the policy-making process. For instance, the AIIB conducts benchmark tests with AfDB, ADB, EBRD, EIB, IaDB, and World Bank when drafting the Public Information Interim Policy to learn from other MDBs [AIIB, 2018b]. On the other hand, AIIB is an active participant in international conferences and networks. The AIIB has attended the Global Infrastructure Forum, the Ethics Network of Multilateral Organization, the Independent Accountability Mechanisms Network with other multilateral organizations. The AIIB has also developed an alignment approach to the Paris Agreement objectives as a member of the family of MDBs on the United Nations Climate Change Conference (COP), which directly influenced the AIIB's thematic priorities and its stance on climate change issues [AIIB, 2018c]. Close 
connections with other MDBs enable the AIIB to learn from and internalize shared ideas and norms within the MDB family.

To sum up, similar educational backgrounds and working experiences of AIIB's senior management and staff, and the active interactions among the MDBs, have created a highly professionalized and homogeneous institutional environment for the AIIB, thus causing the isomorphism. It is consistent with our last hypothesis:

Hypothesis 3: The higher the degree of professionalization and idea-sharing in the institutional environment in which new organizations lie, the more likely the new organization will experience institutional isomorphism.

Conclusion

The case of the AIIB has thought-provoking implications for global governance reform and China's role in it. AIIB President Jin Liqun once explained China's role in the global governance system as a beneficiary, a supporter, and a future reformer who should integrate valuable development experiences into the existing system dominated by developed countries [Sheng, 2019]. Initially, the AIIB was tasked with the mission to innovate the international financial system, with the focus on infrastructure construction and economic growth, avoiding "one-size-fits-all" standards and distinguishing itself from the traditional MDBs. However, it has resembled traditional MDBs during its formative period.

Drawing on the socialization theory of sociological institutionalism, we suggest that pressures from other stakeholders, the AIIB's legitimacy crisis, and the socialized staff of the AIIB have altogether caused the AIIB's institutional isomorphism. Thus, our first implication for China's role in the global governance system is that international institutional environment will constrain China's ability to reform the current system.

Our second implication is that although there are some difficulties for China in changing global governance system at the first place, reforms will be more likely to succeed when China has more discursive power and Chinese-led institutions have more legitimacy. As for the discursive power, if China's proposals are widely accepted as innovative solutions to the global governance and are for the good of mankind, it will 
be easier for China to sell its reform schemes. As for the legitimacy, the AIIB's President Jin Liqun once emphasized that the international society had praised the bank's approval of Indian projects during the China-India border dispute period [Jin, 2021]. He thinks highly of the AIIB's legitimacy more than anything because it is crucial for a newly-established institution to survive at the first place. With the rise of China's discursive power, the development of the AIIB, and even the gradual change of institutional environment of the MDB family, the AIIB may have the potential to break the iron cage.

\section{References}

Accountability Counsel (2018) RE: AIIB Investments in Financial Intermediarie s [online]. Available from: https://www.accountabilitycounsel.org/wp-content/uploa ds/2018/02/Response-to-NGO-Forum-07-2-18.pdf (accessed 8 July 2021).

Asian Development Bank (ADB) (2016) ADB and AIIB Sign Memorandum of Understanding to Strengthen Joint Efforts to Promote Sustainable Growth [onlin e]. Available from: https://www.adb.org/zh/news/adb-aiib-sign-mou-strengthen-coo peration-sustainable-growth (accessed 8 July 2021).

Asian Infrastructure Investment Bank (AIIB) (2015a) Articles of Agreement of the Asian Infrastructure Investment Bank [online]. Available from: http://www.m of.gov.cn/zhengwuxinxi/caizhengxinwen/201506/P020150629360882722541.pdf (ac cessed 30 June 2021).

Asian Infrastructure Investment Bank (AIIB) (2016) Summary of Comments on Energy Issues Note [online]. Available from: https://www.aiib.org/en/policies-strat egies/strategies/.content/index/Summary-of-Comments-on-Issues.pdf (accessed $7 \mathrm{Ju}$ ly 2021). 
Asian Infrastructure Investment Bank (AIIB) (2018a) Accountability Framework [online]. Available from: https://www.aiib.org/en/about-aiib/governance/accountabil ity-framework/index.html (accessed 6 July 2021)

Asian Infrastructure Investment Bank (AIIB) (2018b) Background Paper on the Public Information Interim Policy Review [online]. Available from: https://www. aiib.org/en/policies-strategies/operational-policies/public-consultation/.content/_down load/background_paper_on_PPI.pdf (accessed 8 July 2021).

Asian Infrastructure Investment Bank (AIIB) (2018c) MDBs' Alignment Approa ch to the Objectives of the Paris Agreement [online]. Available from: https://w ww.aiib.org/en/news-events/news/2018/MDBs-Alignment-Approach-to-the-Objective s-of-the-Paris-Agreement.html (accessed 8 July 2021).

Asian Infrastructure Investment Bank (AIIB) (2019a) Energy Sector Strategy: S ustainable Energy for Asia [online]. Available from: https://www.aiib.org/en/polic ies-strategies/strategies/sustainable-energy-asia/.content/index/_download/energy-sect or-strategy.pdf (accessed 30 June 2021).

Asian Infrastructure Investment Bank (AIIB) (2019b) The Fourth Annual Meeti ng of the Board of Governors [online]. Available from: https://www.aiib.org/en/ about-aiib/governance/board-governors/.content/index/_download/Proceedings-of-the -Annual-Meeting-of-the-Board-of-Governors-July-12-13-2019.pdf (accessed 6 Jul y 2021).

Asian Infrastructure Investment Bank (AIIB) (2020a) AIIB Corporate Strategy (2020-2030): Financing Infrastructure for Tomorrow [online]. Available from: ht 
tps://www.aiib.org/en/policies-strategies/strategies/corporate-strategy.html (accessed 1 July 2021).

Asian Infrastructure Investment Bank (AIIB) (2020b) The Fifth Annual Meeting of the Board of Governors [online]. Available from: https://www.aiib.org/en/ab out-aiib/governance/board-governors/.content/index/_download/Gov2020-029-Summ ary-of-Proceedings-of-the-Meeting-of-the-AIIB-Board-of-Governors-2020.pdf (acces sed 6 July 2021).

Asian Infrastructure Investment Bank (AIIB) (2020c) Asian Infrastructure Invest ment Bank: Auditor's Reports and Financial Statements for the Year Ended De c.31, 2020 [online]. Available from: https://www.aiib.org/en/about-aiib/financial-st atements/.content/index/pdf/AIIB-_Annual-Financial-Statements-20201231-signed.pd f (accessed 6 July 2021).

Asian Infrastructure Investment Bank (AIIB) (2021a) AIIB Forecasts Five Key Infrastructure Trends in Post-COVID Recovery [online]. Available from: https:// www.aiib.org/en/news-events/news/2021/AIIB-Forecasts-Five-Key-Infrastructure-Tre nds-in-Post-COVID-Recovery.html (accessed 30 June 2021).

Asian Infrastructure Investment Bank (AIIB) (2021b) Environmental and Social Framework (Approved Febuary 2016, Amended February 2019 and May 2021) [online]. Available from: https://www.aiib.org/en/policies-strategies/_download/env ironment-framework/AIIB-Revised-Environmental-and-Social-Framework-ESF-May -2021-final.pdf (accessed 30 June 2021).

Asian Infrastructure Investment Bank (AIIB) (2021c) Credit Rating Reports [onl ine]. Available from: https://www.aiib.org/en/treasury/_other_content/rating-reports/ index.html (accessed 6 July 2021). 
Asian Infrastructure Investment Bank (AIIB) (2021d) Our Projects [online]. Ava ilable from: https://www.aiib.org/en/projects/list/index.html (accessed 8 July 202 1).

Bankwatch Network (2016) Southern Gas Corridor [online]. Available from: htt ps://bankwatch.org/project/southern-gas-corridor-euro-caspian-mega-pipeline (access ed 7 July 2021).

Bankwatch Network (2017) Nenskra hydropower plant, Georgia [online]. Availa ble from: https://bankwatch.org/project/nenskra-hydropower-plant-georgia\#1561639 919645-1c5e1517-9532 (accessed 7 July 2021).

BIC (2019) Amaravati Sustainable Capital City Development Project [online]. Available from: https://bankinformationcenter.org/en-us/project/amaravati-sustainabl e-capital-city-development-project/ (accessed 7 July 2021).

BRICS (2016) Goa Declaration. Goa, India [online]. Available from: http://ww w.brics.utoronto.ca/docs/161016-goa.html (accessed 1 July 2021).

Brookings Institute (2015) Building Asia's New Bank: An Address by Jin Liqu $\mathrm{n}$, President-designate of the Asian Infrastructure Investment Bank [online]. Ava ilable from: https://www.brookings.edu/events/building-asias-new-bank-an-addressby-jin-liqun-president-designate-of-the-asian-infrastructure-investment-bank/ (access ed 1 July 2021).

Brookings Institute (2021) How we rebuild: A conversation with President Jin Liqun on the Asian Infrastructure Investment Bank's fifth anniversary [online]. Available from: https://www.brookings.edu/events/how-we-rebuild-a-conversationwith-president-jin-liqun-on-the-asian-infrastructure-investment-banks-fifth-anniversar y/ (accessed 7 July 2021). 
Checkel, J. (2005) International Institutions and Socialization in Europe. Interna tional Organization, 59(4), pp.801-826.

Chen, S. (2015) AIIB: A Watershed in Power Transition between U.S. and Chi na? The Chinese Journal of American Studies, 29(3), pp.14-33.

Chin, G. (2019) The Asian Infrastructure Investment Bank-New Multilateralis m: Early Development, Innovation, and Future Agendas. Global Policy, 10(4), pp.569-581.

China Daily (2016) Full text of Chinese President Xi Jinping's address at AII B inauguration ceremony [online]. Available from: https://www.chinadaily.com.cn /bizchina/2016-01/16/content_23116718_2.htm (accessed 30 June 2021).

Devex (2019) Principal/Senior PPM Specialist (Secretariat Services and Dispute Resolution)[online]. Available from: https://www.devex.com/jobs/principal-senior-p pm-specialist-secretariat-services-and-dispute-resolution-659737 (accessed 8 July 2 021).

DiMaggio, P.J., Powell, W.W. (1983) The Iron Cage Revisited: Institutional Iso morphism and Collective Rationality in Organizational Fields. American Sociolo gical Review, 48(2), pp.147-160.

European Bank for Reconstruction and Development (EBRD) (2016) EBRD to Cooperate with Beijing-Based Asian Infrastructure Investment Bank [online]. Av ailable from: https://www.ebrd.com/news/2016/ebrd-to-cooperate-with-beijingbased -asian-infrastructure-investment-bank.html (accessed 8 July 2021). 
Farand, C. (2020) Asian multilateral bank promises to end coal-related financin g. Climate Home News [online], 11 September. Available from: https://www.cli matechangenews.com/2020/09/11/asian-multilateral-bank-promises-end-coal-related -financing/ (accessed 30 June 2021).

Freeman, C. (2019) Constructive Engagement? The US and the AIIB. Global P olicy, 10(4), pp.667-676.

Gabusi, G. (2019) Global Standards in the Asian Infrastructure Investment Ban k: The Contribution of the European Members. Global Policy, 10(4), pp.631-63 8.

Geary, K. (2019) AIIB faces climate protests at annual meeting in Luxembourg. China Dialogue [online], 11 July. Available from: https://chinadialogue.net/zh/3/ 44216/ (accessed 6 July 2021).

Germany Federal Ministry of Finance (2019) Asian Infrastructure Investment B ank achieves major milestones in its first three years [online]. Available from: https://www.bundesfinanzministerium.de/Content/EN/Standardartikel/Topics/Financia 1_markets/Articles/2019-04-03-AIIB-milestones.html (accessed 6 July 2021).

Global Times (2017) AIIB injects new vitality to development of sustainable in frastructure: Chinese finance minister. Available from: https://www.globaltimes.cn /content/1052198.shtml (accessed 30 June 2021).

Gombar, V. (2017) Asian Infrastructure Investment Bank to Reach \$4 Billion i n Loans by Year End: Q\&A [online]. Available from: https://about.bnef.com/blo g/asian-infra-bank-reach-4-billion-loans-year-end-qa/ (accessed 2 July 2021). 
Gransow, B., Price, S. (2018) Social Risk Management at AIIB - Chinese or I nternational Characteristics? Journal of Chinese Political Science, 24(2), pp.289311.

Gu, B. (2019) The Law of the Asian Infrastructure Investment Bank. China: C hinese People's Publishing House.

Guo, S. (2006) On the Role of International Political Socialization on the Dev elopment of International Society. International Review, (2), pp.8-14.

Hall, P., Taylor, R. (1996) Political Science and the Three New Institutionalism s. Political Studies, 44(5), pp.936-957.

$\mathrm{Hu}$, S., Wang, L. and Wang L. (2016) Building the AIIB with the best interna tional innovational guidelines: Interview with the AIIB President Jin Liqun. Cai xin News [online], 15 January. Available from: https://m.weekly.caixin.com/m/20 16-01-15/100899775_all.html.

Humphrey, C., Michaelowa, K. (2013) Shopping for Development: Multilateral Lending, Shareholder Composition and Borrower Preferences. World Developme $n t, 44(4)$, pp.142-155.

Humphrey, C. (2019) Three Years Into Operations: Moving from Concept to R eality at the Asian Infrastructure Investment Bank and New Development Bank. Working Paper of the Inter-Governmental Group of 24 and the Global Develo pment Policy Center of Boston University, pp.1-35.

Hutchens, G. (2016) Australia lobbies infrastructure bank to invest in coal and nuclear power [online]. Available from: https://www.theguardian.com/business/20 
16/dec/06/australia-lobbies-infrastructure-bank-to-invest-in-coal-and-nuclear-power/ (accessed 2 July 2021).

ISS-oekom (2019) ISS-oekom Corporate Rating [online]. Available from: https:// www.aiib.org/en/treasury/_common/_download/oekomCompanyReport_2019-5-3.pdf (accessed 6 July 2021).

Jin, Liqun. (2021) Reform of the International Financial System and China's In fluence [online]. Available from: https://mp.weixin.qq.com/s/8xNo9JvaplOHYd_b 9LAJmw (accessed 27 September 2021).

Johnston, A.I. (2008) Social States: China in International Institutions (1980-20 00). USA: Princeton University Press.

Kellerman, M. (2018) The proliferation of multilateral development banks. The Review of International Organizations, 14(1), pp.1-39.

Legg, C. (2020) AIIB walks the talk on multilateralism [online], 20 September. Available from: https://www.afr.com/world/asia/aiib-walks-the-talk-on-multilaterali sm-20200920-p55xct (accessed 1 July 2021).

Luo, H., Yang, L. (2018) Measuring Power in International Organizations: Fro m Voting Weight to Voting Power: An Analysis of AIIB as an Example. Worl d Economics and Politics, (2), pp.127-154.

Meyer, J.W., Rowan, B. (1977) Institutionalized Organizations: Formal Structure as Myth and Ceremony. American Journal of Sociology, 83(2), pp.340-363. 
Pantucci, R. (2016) China's development lenders embrace multilateral co-operati on [online]. Available from: https://raffaellopantucci.com/tag/aiib/ (accessed 7 Jul y 2021).

Sheng, J. (2019) Jin Liqun: ADB's performance in the three years since its op ening is indisputable. China News Weekly [online], 7 January. Available from: https://baijiahao.baidu.com/s?id=1621957212939691793\&wfr=spider\&for=pc (acces sed 8 July 2021).

Tang. D., Liu. Q. (2017) AIIB plans to "conditionally" support coal power. Ch ina Dialogue [online], 6 March. Available from: https://chinadialogue.net/en/busi ness/9648-aiib-plans-to-conditionally-support-coal-power/ (accessed 2 July 2021).

The Big Shift Campaign (2019) Email the AIIB: Working towards clean, rene wable energy access worldwide [online]. Available from: https://bigshiftglobal.or g/aiib (accessed 6 July 2021).

The Paper (2019) AIIB and BRI are Two Wings of the Same Airplane [onlin e]. Available from: https://www.yidaiyilu.gov.cn/ghsl/gnzjgd/85031.htm (accessed 7 July 2021).

UK Government (2015) UK announces plans to join Asian Infrastructure Invest ment Bank [online]. Available from: https://www.gov.uk/government/news/uk-ann ounces-plans-to-join-asian-infrastructure-investment-bank (accessed 6 July 2021).

VOA (2017) The Relationship between BRI and AIIB [online]. Available from: https://www.voachinese.com/a/voanews-aiib-vp-interview-20170513/3850468.html (accessed 7 July 2021). 
Wang, M. (2016) The Asian Infrastructure Investment Bank: The Construction of Power and the Struggle for the East Asian International Order. United Stat es: Palgrave Macmillan.

Wang H. (2019) The New Development Bank and the Asian Infrastructure Inv estment Bank: China's Ambiguous Approach to Global Financial Governance. Development and Change, 50(1), pp.221-244.

Wilson, J.D. (2019) The evolution of China's Asian Infrastructure Investment B ank: from a revisionist to status-seeking agenda. International Relations of the Asia-Pacific, 19, pp.147-176.

World Bank (2016) World Bank and AIIB Sign First Co-financing Framework Agreement [online]. Available from: https://www.worldbank.org/en/news/press-rel ease/2016/04/13/world-bank-and-aiib-sign-first-co-financing-framework-agreement (accessed 8 July 2021).

World Bank (2018a) Environmental \& Social Framework for IPF Operations E SS4: Community Health and Safety [online]. Available from: http://documents1. worldbank.org/curated/en/290471530216994899/ESF-Guidance-Note-4-CommunityHealth-and-Safety-English.pdf (accessed 7 July 2021).

World Bank (2018b) Environmental \& Social Framework for IPF Operations E SS5: Land Acquisition, Restrictions on Land Use and Involuntary Resettlement [online]. Available from: http://documents1.worldbank.org/curated/en/29433153021 7033360/ESF-Guidance-Note-5-Land-Acquisition-Restrictions-on-Land-Use-and-Inv oluntary-Resettlement-English.pdf (accessed 7 July 2021).

Xu X., Feng W. (2019) The Asian Infrastructure Investment Bank in a Changi ng Era: New Institution and New Roles. China: China Social Sciences Publishi ng House. 
Ye Y. (2020) The Evolving Multilateral Development Banks and Their Coordin ation. China: Shanghai People's Publishing House.

Zhao, K. (2015) EU's Asia-Pacific Policy: A New Engagement? How to Under stand the Behavior Logic in the EU Member States' Entry into AIIB. Chinese Journal of European Studies, 33(2), pp.16-28.

Zhu, J. (2018) Institutional Choice of the Operational Modalities of the New MDBs: A Historical Institutionalist Perspective. World Economics and Politics, (8), pp.30-61.

Zhu, J. (2019) Is the AIIB a China-controlled Bank? China's Evolving Multilat eralism in Three Dimensions. Global Policy, 10(4), pp.653-659. 